УДК 796.03+796.5

doi: 10.15330/fcult.36.108-116

\author{
Андрій Полтавець, Вячеслав Мулик, Андрій Кийко
}

\title{
ОЦІНКА ЕМОЦІЙНО-ВОЛЬОВОЇ СФЕРИ ТА РЕАКТИВНОЇ ТРИВОЖНОСТІ КУРСАНТІВ В КОНТЕКСТІ РОЗРОБКИ МОДЕЛІ ТРЕНУВАЛЬНОГО КОМПЛЕКСУ ДЛЯ СПОРТСМЕНІВ З ВІЙСЬКОВО-АВІАЦІЙНОГО П' ЯТИБОРСТВА
}

\begin{abstract}
Мета. Оиінка, емоційно-вольової сфери, реактивної тривожності а також їх зміни за умов ознак втоми після стрес-тесту методом кросфіту у курсантів в контексті планування тренувальної діяльності з військово-авіаційного п'ятиборства. Методи. В дослідженні використані наступні методи: анкетування, психологічне тестування, математично-статистичний аналіз. У педагогічному експерименті приймали участь 48 курсантів периого курсу Харківського національного університету Повітряних Сил імені Івана Кожедуба (чоловіки), віком 17-18 років, з них 38 кандидатів в майстри та 10 майстрів спорту. Рівень ситуативної (реактивної) тривожності визначали за тестом Ч. Спілбергера. Для оцінки стабільності емочійної сфери використовували показник емоційної лабільності за шкалою самопочуття В.А. Доскіна. Статистичну обробку отриманих даних проводили параметричним методом, а перевірку значущзості отриманих даних здійснювали за допомогою t-критерія Стьюдента (для $n<100)$ при заданому рівні надійності $p=0$,95. Результати. Встановлені вихідні показники курсантівспортсменів, кандидатів для подальшої тренувальної діяльності з військово-авіаційного п'ятиборства. Проведено розподіл кандидатів за такими видами спорту як ігрові, циклічні, складно-координаційні види та спортивні єдиноборства. Враховуючи те, щзо емоційно-вольова сфера, реактивна тривожність та когнітивні здібності є інтегрольними показниками прояву індивідуальних якостей кожного із спортсменів, були відібрані психофізичні тести, дані яких свідчать про найважливіші властивості емоційновольової сфери спортсменів, щзо можуть бути використані для прогнозування результату головних змагань з військово-авіаційного n'ятиборства. Висновок. Встановлена гетерогенність вихідних показників емоиійно-вольової сфери, реактивної тривожності та когнітивних здібностей кандидатів в збірну команду з військово-авіачійного п'ятиборства. Обгрунтована необхідність розробки єдиного універсального алгоритму тренування з визначенням обов'язкових контрольних точок - періодів оцінки провідних психофізичних здібностей та розроблено комплекс допоміжних спортивних вправ (кросфіту) для покращення тих чи інших показників емоційно-вольової сфери, реактивної тривожності та когнітивних здібностей курсантів у відповідності до конкретного виду спорту.
\end{abstract}

Ключові слова: військово-авіаційне п'ятиборство, смуга перешкод, кросфіт, емочійно-вольова сфера, реактивна тривожність, курсанти.

Aim. Assessment of emotional and volitional sphere, reactive anxiety and their changes in terms of signs of fatigue after the stress test by the crossfit method in cadets in the context of planning training activities in military aviation pentathlon. Methods. The following methods were used in the study: questionnaires, psychological testing, mathematical and statistical analysis. The pedagogical experiment was attended by 48 first-year cadets of the Ivan Kozhedub Kharkiv National University of the Air Force (men), aged 17-18, including 38 candidates for masters and 10 masters of sports. The level of situational (reactive) anxiety was determined by the Spielberger test. To assess the stability of the emotional sphere used an indicator of emotional lability on the scale of well-being VA Doskin. Statistical processing of the obtained data was performed by the parametric method, and verification of the significance of the obtained data was performed using Student's $t$-test (for $n<100$ ) at a given level of reliability $p=0.95$. Results. The initial indicators of cadets-athletes, candidates for further training activities in military aviation pentathlon have been set. The distribution of candidates by such sports as game, cyclic, complex-coordination sports and martial arts is carried out. Given that the emotional-volitional sphere, reactive anxiety and cognitive abilities are integral indicators of the manifestation of individual qualities of each athlete, psychophysical tests were selected, which show the most important properties of the emotional-volitional sphere of athletes that can be used to predict the outcome. in military aviation pentathlon. Conclusion. The heterogeneity of the initial indicators of the emotional and volitional sphere, reactive anxiety and cognitive abilities of the candidates for the national team in military aviation pentathlon has been established. Necessity of development of the uniform universal algorithm of training with definition of obligatory control points - periods of an estimation of leading psychophysical abilities is proved and the complex of auxiliary sports exercises (crossfit) for improvement of these or those indicators of emotional and volitional sphere, reactive anxiety and cognitive abilities to cadets is developed. sport.

Key words: military aviation pentathlon, obstacle course, crossfit, emotional and volitional sphere, reactive anxiety, cadets. 
Постановка проблеми й аналіз результатів останніх досліджень. Відомо, що однією із найбільш складних компетенцій, якою повинен володіти спортсмен з військово-авіаційного п'ятиборства (ВАП), є подолання смуги перешкод в комплексі із спортивним орієнтуванням $[10,11]$.

Під час проходження смуги перешкод організм спортсмена зазнає психофізичного стресу, що в більшості випадків, при відсутності спеціальної попередньої підготовки, може призводити до погіршення лабільності емоційно-вольової сфери й зниженню когнітивних можливостей спортсмена $[10,19]$.

Незаперечним $є$ те, що спортивне орієнтування є одним з найбільш специфічних видів спорту, в якому поєднуються високі фізичні і розумові навантаження на тлі великих вольових і емоційних напружень, спрямованих на самостійне вирішення низки практичних завдань $[1,11]$. Саме тому цей сегмент змагань спортивного конкурсу 3 ВАП пред'являє високі вимоги до механізмів пам'яті (сприйняття, синтезу, аналізу інформації) та уваги - здатності спортсмена спрямовувати свою рухову діяльність на вирішення завдань, пов'язаних з проходженням дистанції в складних географічних умовах [13]. При підвищенні складності дистанцій в орієнтуванні навантаження на фізіологічні механізми сприйняття і переробки інформації $є$ безперервним. Відтак, застосування спеціальних вправ, спрямованих на розвиток пам'яті та уваги у спортсменів з ВАП є обов'язковою умовою для підвищення ефективності тренувальної i змагальної діяльності [20].

Важливим критерієм успішної реалізації в умовах змагань розвинутих психофізичних здібностей під час тренувань є здатність керувати таким емоційним станом, як тривожність [8]. Змагання зі спортивного орієнтування є серйозним випробуванням для основних фізичних якостей спортсмена - витривалості, силових і швидкісних здібностей, вольових якостей, здатності якісно виконувати операції мислення, приймати правильні рішення на тлі втоми, яка прогресує під час спортивних змагань з ВАП [26, 27]. При цьому причиною помилок в орієнтуванні є також підвищена ситуативна тривожність та послабленням уваги $[23,25]$. Враховуючи вище викладене, важливим $\epsilon$ розвиток у спортсменів під час тренувань резистентності до психоемоційного стресу, який посилюється під впливом зміни гормонального фону внутрішнього середовища організму під час змагань з ВАП.

Провідною концепцією нашого дослідження $є$ той факт, що для отримання функціональних ефектів (формування фізіологічних резервів головних фізіологічних систем, досягнення економізації функцій) потрібні тренувальні впливи з відповідною тривалістю, частотою та інтенсивністю, які постійно змінюються з урахуванням досягнутого рівня розвитку рухових здібностей [24]. Однак, безперервний розвиток будь-якої якості $\epsilon$ неможливий. Удосконалення структурно-функціональних властивостей організму спортсмена може бути реалізовано через застосування засобів і методів, спрямованих на удосконалення інших психофізичних здібностей [7], в тому числі складових емоційно-вольової сфери та когнітивних механізмів.

Мета дослідження - оцінка, емоційно-вольової сфери, реактивної тривожності у курсантів, а також їх зміни за умов ознак втоми після стрес-тесту методом кросфіту в контексті планування тренувальної діяльності з військово-авіаційного п'ятиборства.

Методи дослідження. В дослідженні приймали участь 48 курсантів першого курсу Харківського національного університету Повітряних Сил імені Івана Кожедуба (чоловіки), віком 17--8 років, 3 них 38 кандидатів у майстри та 10 майстрів спорту. Всі курсанти для подальшої тренувальної діяльності з військово-авіаційного п'ятиборства були розподілені на чотири групи за видами спорту, а саме: ігрові (група I - 12 курсантів), циклічні (група II - 14 курсантів), складно-координаційні (група III - 10 курсан- 
тів), спортивні єдиноборства (група IV - 12 курсантів). Курсанти, що приймали участь у досліджені були рандомізовані за віком, антропометричними показниками та станом соматичного здоров'я.

Для визначення рівня психофізичної готовності курсантів до досягнення високих результатів під час змагань з ВАП (смуга перешкод, спортивне орієнтування) використовували коловий стрес-тест методом кросфіту (біг 400 м, L-підтягування 10 разів, бурпі 20 разів, стрибки на скакалці 30 с, згинання і розгинання рук в упорі лежачи 20 разів, стрибок на тумбу висотою 45 см 10 разів). Підраховували кількість повних кругів за умов якісного виконання вправ протягом 30 хвилин. Обов'язковою складовою стрес-тесту методом кросфіту було правильне виконання вправ 3 прагненням здійснити максимально можливу кількість кругів.

Рівень ситуативної (реактивної) тривожності (РТ) визначали за тестом Ч. Спілбергера [14].

Для оцінки стабільності емоційної сфери використовували показник емоційної лабільності за шкалою самопочуття В.А. Доскіна [2].

Статистичну обробку отриманих даних проводили параметричним методом [6]. Перевірку значущості отриманих даних здійснювали за допомогою t-критерія Стьюдента (для $\mathrm{n}<100$ ) при заданому рівні надійності $\mathrm{p}=0,95$. Для можливості використання критерія Стьюдента обчислювали критерій Фішера-Снедекора - відношення більшої дисперсії до меншої. Усі математичні операції і графічні побудови проведені з використанням програмних пакетів "Microsoft Office XP": "Microsoft XP Home" i “Microsoft Excel XP” на персональному комп'ютері.

Результати дослідження. В табл. 1 наведені дані щодо вихідного рівня ситуативної тривожності курсантів-спортсменів.

Таблиия 1

Стан реактивної тривожності курсантів першого курсу за тестом

Ч. Спілбергера, $\bar{x}+m$

\begin{tabular}{|c|c|c|c|c|}
\hline \multirow{2}{*}{$\begin{array}{c}\text { Рівень ситуативної } \\
\text { тривожності, бали }\end{array}$} & \multicolumn{4}{|c|}{ Групи } \\
\hline & $\mathrm{I}(\mathrm{n}=12)$ & II $(n=14)$ & III $(n=10)$ & IV $(n=12)$ \\
\hline $\begin{array}{l}\leq 30 \text { балів - низький } \\
\text { рівень }\end{array}$ & $26,1 \pm 0,7$ & $28,2 \pm 1,2$ & $28,4 \pm 0,9$ & $29,1 \pm 0,8$ \\
\hline $\begin{array}{l}\text { Низький рівень: } \\
t, p\end{array}$ & \multicolumn{4}{|c|}{$\begin{array}{c}\mathrm{t}_{1,2}=1,54\left(\mathrm{p}_{1,2}>0,05\right) ; \mathrm{t}_{1,3}=1,41\left(\mathrm{p}_{1,3}>0,05\right) ; \\
\mathrm{t}_{1,4}=1,59\left(\mathrm{p}_{1,4}>0,05\right) ; \mathrm{t}_{2,3}=1,39\left(\mathrm{p}_{2,3}>0,05\right) ; \\
\mathrm{t}_{2,4}=1,45\left(\mathrm{p}_{2,4}>0,05\right) ; \mathrm{t}_{3,4}=0,56\left(\mathrm{p}_{3,4}>0,05\right)\end{array}$} \\
\hline $\begin{array}{l}31-44 \text { бали - середній } \\
\text { рівень }\end{array}$ & $33,6 \pm 1,4$ & $38,2 \pm 1,1$ & $35,4 \pm 0,9$ & $42,6 \pm 1,1$ \\
\hline $\begin{array}{l}\text { Середній рівень: } \\
t, p\end{array}$ & \multicolumn{4}{|c|}{$\begin{array}{l}\mathbf{t}_{1,2}=\mathbf{2 , 2 1}\left(\mathbf{p}_{\mathbf{1 , 2}}<\mathbf{0 , 0 5}\right) ; \mathrm{t}_{1,3}=1,44\left(\mathrm{p}_{1,3}>0,05\right) ; \\
\mathbf{t}_{\mathbf{1 , 4}}=\mathbf{2 , 5 3}\left(\mathbf{p}_{\mathbf{1 , 4}}<\mathbf{0 , 0 5}\right) ; \mathbf{t}_{\mathbf{2}, 3}=\mathbf{2 , 5 7}\left(\mathbf{p}_{\mathbf{2}, \mathbf{3}}<\mathbf{0 , 0 5}\right) ; \\
\mathbf{t}_{\mathbf{2}, \mathbf{4}}=\mathbf{2 , 4 2}\left(\mathbf{p}_{\mathbf{2 , 4}}<\mathbf{0 , 0 5}\right) ; \mathbf{t}_{\mathbf{3}, \mathbf{4}}=\mathbf{2 , 2 3}\left(\mathbf{p}_{\mathbf{3}, 4}<\mathbf{0 , 0 5}\right) ;\end{array}$} \\
\hline $\begin{array}{l}\geq 45 \text { балів - високий } \\
\text { рівень }\end{array}$ & 0 & $45,8 \pm 0,4$ & $45,9 \pm 0,7$ & $46,1 \pm 0,9$ \\
\hline $\begin{array}{l}\text { Високий рівень: } \\
t, p\end{array}$ & \multicolumn{4}{|c|}{$\begin{array}{c}\mathrm{t}_{1,2}=1,52\left(\mathrm{p}_{1,2}>0,05\right) ; \mathrm{t}_{1,3}=1,43\left(\mathrm{p}_{1,3}>0,05\right) ; \\
\mathrm{t}_{1,4}=1,57\left(\mathrm{p}_{1,4}>0,05\right) ; \mathrm{t}_{2,3}=1,37\left(\mathrm{p}_{2,3}>0,05\right) ; \\
\mathrm{t}_{2,4}=1,44\left(\mathrm{p}_{2,4}>0,05\right) ; \mathrm{t}_{3,4}=0,58\left(\mathrm{p}_{3,4}>0,05\right)\end{array}$} \\
\hline
\end{tabular}

При проведенні аналізу даних табл. 1 встановлено, що низький рівень ситуативної тривожності характерний для 6 (50\%) спортсменів-представників ігрових видів спорту - I група, 3 (30\%) спортсменів III групи (складно-координаційні види спорту), 4 (28\%) спортсменів II групи, (ігрові види спорту) та у 2 (17\%) курсантів IV групи (спортивні єдиноборства). при цьому вірогідних відмінностей між групами не 
виявлено. При цьому вірогідних відмінностей між групами не встановлено (див. табл.1).

Середній рівень РТ у I групі був виявлений у 6 (50\%) спортсменів, в II групі - у $5(36 \%)$ курсантів і вірогідно $(\mathrm{p}<0,05)$ був нижчим від даного показника в IV групі, де таких спортсменів було 7 (58\%) Необхідно відзначити, що II групі спортсменів ситуативна тривожність була вірогідно більшою ніж в III групі і меншою за представників IV групи (див. табл.1).

В свою чергу, у курсантів III групи показник РТ виявився вірогідно більшим ніж в I, II і III групах (див. табл.1).

Отже можна констатувати, що найбільше спортсменів з середнім рівнем ситуативної тривожності, який наближався до високого, виявлено в IV групі, а найменше, що наближався до низького - у спортсменів I групи.

Високий рівень реактивної тривожності виявлено у 5 (36\%) спортсменів II групи, 3 (30\%) курсантів III групи і 3 (25\%) представників IV групи, без вірогідної різниці між групами (див. табл. 1).

Таким чином, незважаючи на високі спортивні досягнення під час зарахування до навчального закладу, значний тренувально-змагальний стаж та психологічну підготовленість до участі в змаганнях, перед проходженням стрес-тесту методом кросфіт, який був майже прототипом за скороченим варіантом смуги перешкод - провідного змагального етапу з ВАП, нами були отримані гетерогенні показники ситуативної тривожності в досліджуваних групах курсантів. Так, найбільша кількість спортсменів 3 максимальними показниками в діапазонах середніх/високих значень РТ була виявлена в IV групі (спортивні єдиноборства), що може бути зумовлено специфікою даного виду спорту. Водночас, в ігрових (командних) видах спорту (I група), не було виявлено жодного випадку РТ високого рівня. В II і III групах (циклічні та складно-координаційні види спорту), розподіл курсантів за виразністю РТ був майже ідентичним кількість досліджуваних 3 низьким, середнім та високим рівнем даного показника складала $30-40 \%$.

При визначенні стабільності емоційної сфери опитування проводили до та після стрес-тесту методом кросфіт. Враховуючи, що останній день змагань 3 ВАП складається 3 двох етапів - подолання смуги перешкод та “легенди” із спортивного орієнтування - важливою умовою для отримання кращого результату є стабільність показників самопочуття, активності і настрою, який ми проводили після проходження стрес-тесту, який вважався нами прототипом смуги перешкод.

При проведенні аналізу даних табл. 2 щодо показників самопочуття, які відображають суб'єктивну оцінку сили, загального здоров'я та стомлення, активності, що характеризують рухливість, швидкість і темп протікання функцій та настрою, що вказують на емоційний стан не встановлено вірогідних відмінностей між групами досліджуваних і зафіксовано їх добрі величини (виключно у всіх курсантів вони були у діапазоні 5,5-7,0 балів). При цьому, як було відзначено вище, показник рівня ситуативної тривожності перед стрес-тестом методом кросфіт мав вірогідні відмінності між групами, що залежало від виду спортивної діяльності курсантів.

I так, після стрес-тесту у спортсменів I групи (ігрові види спорту) самопочуття характеризувалося як добре, в жодному разі кількість балів не зменшувалось до діапазону, що характеризує середній рівень В II групі середній рівень самопочуття був вірогідно меншим від даного показника в III і IV групах, що вказує на менший рівень відчуття стомлення у курсантів, які на момент вступу до навчального закладу мали високі спортивні досягнення в складно-координаційних видах спорту та спортивних єдиноборствах. 
При проведенні аналізу показника активності після стрес-тесту методом кросфіт у всіх групах досліджуваних виявлено його “добрий стан”. При цьому у $30 \%$ курсантів I групи виявлено середній рівень активності, який був вірогідно меншим, порівняно зі спортсменами IV групи. В II групі активність виявилася на доброму рівні у $60 \%$ курсантів, а в 4\% мала середню величину і була вірогідно меншою, ніж в IV групі. Щодо III групи, то показник активності у 30\% спортсменів відповідав діапазону “дуже добре”, а в 70\% - “добре” (див. табл. 2).

Таблиия 2

Стан емоційної лабільності курсантів-спортсменів першого курсу за шкалою самопочуття до і після стрес-тесту, $\overline{\mathrm{x}}+m$

\begin{tabular}{|c|c|c|c|c|}
\hline \multirow[t]{2}{*}{ Рівень емоційної лабільності, бали } & \multicolumn{4}{|c|}{ Групи } \\
\hline & $\mathrm{I}(\mathrm{n}=12)$ & II $(n=14)$ & III $(n=10)$ & IV $(n=12)$ \\
\hline \multicolumn{5}{|c|}{ Самопочуття } \\
\hline До стрес-тесту & $6,2 \pm 0,7$ & $6,4 \pm 0,6$ & $6,1 \pm 0,4$ & $6,4 \pm 0,7$ \\
\hline Самопочуття до стрес-тесту: $\mathrm{t}, \mathrm{p}$ & \multicolumn{4}{|c|}{$\begin{array}{c}\mathrm{t}_{1,2}=0,11\left(\mathrm{p}_{1,2}>0,05\right) ; \mathrm{t}_{1,3}=1,42\left(\mathrm{p}_{1,3}>0,05\right) ; \\
\mathrm{t}_{1,4}=0,27\left(\mathrm{p}_{1,4}>0,05\right) ; \mathrm{t}_{2,3}=0,23\left(\mathrm{p}_{2,3}>0,05\right) ; \\
\mathrm{t}_{2,4}=0,14\left(\mathrm{p}_{2,4}>0,05\right) ; \mathrm{t}_{3,4}=0,62\left(\mathrm{p}_{3,4}>0,05\right)\end{array}$} \\
\hline Після стрес-тесту & $4,9 \pm 0,4$ & $4,6 \pm 0,2$ & $5,2 \pm 0,2$ & $5,1 \pm 0,2$ \\
\hline Самопочуття після стрес-тесту: $\mathrm{t}, \mathrm{p}$ & \multicolumn{4}{|c|}{$\begin{array}{c}\mathrm{t}_{1,2}=0,31\left(\mathrm{p}_{1,2}>0,05\right) ; \mathrm{t}_{1,3}=1,46\left(\mathrm{p}_{1,3}>0,05\right) ; \\
\mathrm{t}_{1,4}=1,62\left(\mathrm{p}_{1,4}>0,05\right) ; \mathrm{t}_{2,3}=2,19\left(\mathrm{p}_{2,3}<0,05\right) ; \\
\mathrm{t}_{2,4}=2,42 \mathrm{p}_{2,4}<0,05 ; \mathrm{t}_{3,4}=0,38\left(\mathrm{p}_{3,4}>0,05\right)\end{array}$} \\
\hline \multicolumn{5}{|c|}{ Активність } \\
\hline До стрес-тесту & $6,4 \pm 0,4$ & $6,6 \pm 0,4$ & $6,4 \pm 0,6$ & $6,3 \pm 0,2$ \\
\hline $\begin{array}{c}\text { Активність до стрес-тесту: } \\
\text { t, p }\end{array}$ & \multicolumn{4}{|c|}{$\begin{array}{c}\mathrm{t}_{1,2}=0,10\left(\mathrm{p}_{1,2}>0,05\right) ; \mathrm{t}_{1,3}=1,44\left(\mathrm{p}_{1,3}>0,05\right) ; \\
\mathrm{t}_{1,4}=0,26\left(\mathrm{p}_{1,4}>0,05\right) ; \mathrm{t}_{2,3}=0,21\left(\mathrm{p}_{2,3}>0,05\right) ; \\
\mathrm{t}_{2,4}=0,13\left(\mathrm{p}_{2,4}>0,05\right) ; \mathrm{t}_{3,4}=0,63\left(\mathrm{p}_{3,4}>0,05\right)\end{array}$} \\
\hline Після стрес-тесту & $4,5 \pm 0,4$ & $4,6 \pm 0,3$ & $5,1 \pm 0,6$ & $5,2 \pm 0,2$ \\
\hline Активність після стрес-тесту: t, p & \multicolumn{4}{|c|}{$\begin{array}{l}\mathrm{t}_{1,2}=0,32\left(\mathrm{p}_{1,2}>0,05\right) ; \mathrm{t}_{1,3}=1,41\left(\mathrm{p}_{1,3}>0,05\right) ; \\
\mathrm{t}_{1,4}=3,26\left(\mathrm{p}_{1,4}<0,01\right) ; \mathrm{t}_{2,3}=0,21\left(\mathrm{p}_{2,3}>0,05\right) ; \\
\mathrm{t}_{2,4}=2,44\left(\mathrm{p}_{2,4}<0,05\right) ; \mathrm{t}_{3,4}=0,36\left(\mathrm{p}_{3,4}>0,05\right)\end{array}$} \\
\hline \multicolumn{5}{|c|}{ Настрій } \\
\hline До стрес-тесту & $6,4 \pm 0,4$ & $6,3 \pm 0,6$ & $6,1 \pm 0,2$ & $6,4 \pm 0,6$ \\
\hline $\begin{array}{c}\text { Настрій до стрес-тесту: } \\
\text { t, p }\end{array}$ & \multicolumn{4}{|c|}{$\begin{aligned} & \mathrm{t}_{1,2}=0,12\left(\mathrm{p}_{1,2}>0,05\right) ; \mathrm{t}_{1,3}=1,42\left(\mathrm{p}_{1,3}>0,05\right) \\
& \mathrm{t}_{1,4}=0,28\left(\mathrm{p}_{1,4}>0,05\right) ; \mathrm{t}_{2,3}=0,22\left(\mathrm{p}_{2,3}>0,05\right) \\
& \mathrm{t}_{2,4}=0,16\left(\mathrm{p}_{2,4}>0,05\right) ; \mathrm{t}_{3,4}=0,61\left(\mathrm{p}_{3,4}>0,05\right)\end{aligned}$} \\
\hline Після стрес-тесту & $4,5 \pm 0,4$ & $4,6 \pm 0,6$ & $5,8 \pm 0,2$ & $6,1 \pm 0,4$ \\
\hline $\begin{array}{c}\text { Настрій після стрес-тесту: } \\
\text { t, p }\end{array}$ & \multicolumn{4}{|c|}{$\begin{array}{l}\mathrm{t}_{1,2}=0,11\left(\mathrm{p}_{1,2}>0,05\right) ; \mathrm{t}_{1,3}=3,25\left(\mathrm{p}_{1,3}<0,05\right) ; \\
\mathrm{t}_{1,4}=3,27\left(\mathrm{p}_{1,4}<0,01\right) ; \mathrm{t}_{2,3}=3,21\left(\mathrm{p}_{2,3}<0,01\right) ; \\
\mathrm{t}_{2,4}=2,46\left(\mathrm{p}_{2,4}<0,05\right) ; \mathrm{t}_{3,4}=0,62\left(\mathrm{p}_{3,4}>0,05\right)\end{array}$} \\
\hline
\end{tabular}

Аналіз даних щодо стану настрою після стрес-тесту було виявлено найбільшу кількість вірогідних відмінностей між досліджуваними групами. Так, у 80\% курсантів I i II груп цей показник мав середній і у 20\% добрий рівень. У III і IV групах, навпаки, показник "настрій" після проходження стрес-тесту методом кросфіт залишався на доброму та дуже доброму рівні у переважної кількості досліджуваних. При цьому вірогідними були відмінності емоційного стану після стрес-тесту між показниками настрою в групах I i III, I i IV, II і III, II i IV (див. табл. 2).

При проведенні аналізу показника “стан настрою” після стрес-тесту було виявлено найбільшу кількість вірогідних відмінностей між досліджуваними групами. Відтак, у 80\% спортсменів I і II груп констатовано середній, а в $20 \%$ добрий рівень цього показника. У III i IV групах, навпаки, настрій після проходження стрес-тесту 
методом кросфіт залишався на доброму та дуже доброму рівні у переважної кількості досліджуваних. При цьому, вірогідними були відмінності емоційного стану після стрестесту між показниками настрою в I і III, I і IV, II і III, II і IV групах (див. табл. 2).

Зважаючи на отримані показники емоційної сфери у курсантів-спортсменів всіх 4-х груп після проходження стрес-тесту методом кросфіт, який був застосований нами як прототип смуги перешкод, можна констатувати, що вони $є$ важливими для прогнозування швидкості проходження і якості вирішення “легенди” в спортивному орієнтуванні і безпосередньо впливає на загальний результат змагань 3 військовоавіаційного п'ятиборства..

\section{Дискусія.}

За даними досліджень В.I. Воронової [5], інтелектуальний розвиток, емоційна зрілість і соціалізація особистості $\epsilon$ підгрунтям для формування психологічної готовності спортсменів до участі в спортивній діяльності: в сукупності з розвитком здатності до максимальної реалізації фізичних можливостей, формуються механізми економізації витрат психоенергетичного потенціалу особистості [27].

Поряд із функціональною та техніко-тактичною готовністю, до специфічного передстартового комплексу, що утворює структуру готовності спортсмена до виступу у змаганнях, вчені відносять: емоційно-вольову стійкість, цілеспрямованість особистості, наполегливість, здатність до мобілізації, психологічну витривалість (в умовах наростання втоми та стомлення), самоконтроль, рішучість, волю до перемоги, спортивну злість, а також самоконтроль та активну саморегуляцію $[12,16]$. Отримані нами результати ще раз доводять необхідність застосування психологічних тестувань спортсменів на різних етапах підготовки і особливо при підготовці до головних змагань.

У психологічних дослідженнях здійснюється диференціація двох видів тривожності - особистісної та ситуативної (реактивної) тривожності [8]. У контексті мети нашого дослідження на особливий інтерес заслуговують роботи, присвячені вивченню тривожності як стійкого емоційно-особистісного утворення $[4,15]$. Цими дослідниками тривожність розглядається як своєрідний сигнал, попередження про можливі порушення в психофізичній сфері особистості. Спортсмен, який спеціалізується в військовоавіаційному п'ятиборстві, особливо зі стійким підвищеним рівнем тривожності, поступово починає спотворювати сприймання реальності, а отже, тривожність $є$ проявом конфлікту “Я-концепції”. Це підтверджується результатами досліджень, присвячених вивченню як самої тривожності, так і психологічних утворень, до складу яких вона включена. Необхідно підкреслити, що основною причиною тривожності спортсменів $€$ конфлікт, неузгодженість рівнів самооцінки та особистих домагань [7, 19].

Для розуміння причин тривожності спортсменів актуальним $є$ питання щодо локалізації іiі джерел. Результати наших досліджень дозволяють виділити два типи джерел підвищеної тривожності. Першим і найбільш поширеним джерелом є тривала зовнішня стресова ситуація, що виникає внаслідок частих переживань суб'єктом станів тривоги [18]. До другого джерела, що провокує розвиток стійкої тривожності у спортсменів, необхідно віднести внутрішні психофізіологічні чинники (відсутність належного рівня концентрації уваги та функціональних резервів головних фізіологічних систем). Причини його виникнення вчені пов'язують із суб'єктивними та об'єктивними факторами: незадовільним станом здоров'я спортсменів, недостатнім рівнем підготовленості, неадекватно високим рівнем відповідальності за результат виступу, досвідом минулих невдалих виступів, силою суперників, відсутністю особистісної впевненості в успіху, а також індивідуально-психофізіологічними властивостями собистості спортсмена зокрема, резистентністю до впливу стресогенних факторів [2]. Вважаємо, що метод кросфіту $є$ таким, який найбільш відповідає вимогам щодо універсального 
комплексу фізичних вправ для підготовки до змагань 3 військово-авіаційного п'ятиборства так як усуває цілу низку як суб'єктивних, так і об'єктивних факторів підвищеної тривожності у спортсменів.

\section{Висновок.}

Встановлена гетерогенність вихідних показників емоційно-вольової сфери, реактивної тривожності та когнітивних здібностей кандидатів в збірну команду з військовоавіаційного п'ятиборства. Обгрунтована необхідність розробки єдиного універсального алгоритму тренування з визначенням обов'язкових контрольних точок - періодів оцінки провідних психофізичних здібностей та розроблено комплекс допоміжних спортивних вправ (кросфіту) для покращення тих чи інших показників емоційновольової сфери, реактивної тривожності та когнітивних здібностей курсантів у відповідності до конкретного виду спорту.

1. Аулик ИВ. Определение физической работоспособности в клинике и спорте. М., 1990. 147 с.

2. Бабушкин ГД. Психолого-педагогическое обеспечение подготовки спортсменов к соревнованиям. Омск, 2007. $90 \mathrm{c}$.

3. Барканова ОВ. Методики діагностики емоційної сфери: психологічний практикум. Красноярськ: Літера-принт, 2009; 2: 237 с.

4. Бойко ГМ. Психологічна структура спортивної діяльності плавців у паралімпійському спорті. Педагогіка, психологія та медико-біологічні проблеми фізичного виховання і спорту: 2007; 9: 19-24.

5. Воронова В, Корнейко У. Показатели психологической готовности высоко квалифицированных спортсменов. Олимпийский спорт и спорт для всех: тезисы V Международного научного конгресса (5-7 июня 2001). Минск: БелорусскаяГАФК, 2001: 395.

6. Гланц С. Медико-биологическая статистика. Пер. с англ. М., Практика, 1998. 459 с.

7. Ильин ЕП. Психология спорта. Санкт-Петербург: Питер 2019. 352 с.

8. Ильин ЕП, Семенов МС. Психофизиологические основы физического воспитания и спорта. Ленинградский государственный педагогический институт им. А. И. Герцена, Ленинград, 1972. 186 с.

9. Карелин АА. Большая энциклопедия психологических тестов. М.: Эксмо, 2007. 416 с.

10. Кирпенко BM, Золочевський BB, Полтавець AI. Подолання перешкод. Смуга перешкод CISM. Харків: ХНУПС ім. І.Кожедуба, 2020. 104 с.

11. Кирпенко ВМ, Піддубний ОГ, Полтавець АI. Аеронавтичне багатоборство. Харків: ХНУПС ім. І.Кожедуба, 2016. 168 с.

12. Крылов АА. Некоторые проблемы психологии спорта в современном мире. Спортивная психология в трудах отечественных специалистов / сост. и общая ред. И.П. Волкова. СПб.: Питер, 2002: 37-42.

13. Ланда БХ. Методика комплексной оценки физического развития и физической подготовленности. М.: Советский спорт, 2011. 348 с

14. Мицкан Т, Мицкан Б. Психодіагностика в спорті. Івано-Франківськ: Видавець Кушнір Г.М., 2020. $228 \mathrm{c}$.

15. Рейковский Я. Экспериментальная психология эмоций. М.: Прогресс, 1989. 297 с.

16. Стамбулова НБ. Психологическая структура спортивной деятельности. Спортивная психология в трудах отечественных психологов./ Сост. И.П. Волков. СПб.: Питер, 2002: 32-37.

17. Тукаев СВ, Долгова ЕН, Руженкова АО, Лысенко ЕН, Федорчук СВ, Гаврилец ЮД, Ризун ВВ, Шинкарук ОА. Типологические и личностные детерминанты стрессоустойчивости у спортсменов экстремальных видов спорта. Спортивна медицина, фізична терапія та ерготерапія. 2017; 2: 8-15.

18. Ханин ЮЛ. Психология общения в спорте. М.: Физкультура и сnоpm, 1980. 208 с.

19. Щеголев ВА, Сивак АН, Кочин АА, Егоров ВЮ. Подготовка специалистов военно-спортивного профиля в вооруженных силах ведущих стран НАТО. Теория и практика физической культуры. 2016; 2: 61-66.

20. Щербаков МА, Лянной МО. Основи спортивного орієнтування : навчально-методичні рекомендації. Вид-во СумДПУ імені А. С. Макаренка, Суми, 2015. 32 с.

21. Brymer E \& Schweitzer R. Extreme sports are good for your health: a phenomenological understanding of fear and anxiety in extreme sport. Journal of health psychology. 2013; 18(4): 477-487. Retrieved from PMID: 22689592, doi: 10.1177/1359105312446770.

22. Galli N, Gonzalez SP. Psychological resilience in sport: A review of the literature and implications for research and practice. International Journal of Sport and Exercise Psychology. 2015; 13(3): 243-257. Retrieved from doi: http://dx.doi.org/10.1080/1612197X.2014.946947. 
23. Knapik J, Sharp M, Darakjy S. Temporal changes in the physical fitness of US army recruits, Sports Med. 2006; 36: 613-634.

24. Leyk D, Erley O, Ridder D, Leurs A. Age related changes in marathon and half-marathon performances. Int J Sports Med, 2007; 28: 513-517.

25. Osipov A, Kudryavtsev M, Gatilov K. The use of functional training - crossfit methods to improve the level of special training of athletes who specialize in combat sambo. Journal of Physical Education and Sport. 2017; 17 (3): 2013-2018.

26. Pattyn N., Coeckelberghs E., Buys R. Aerobic interval training vs. moderate continuous training in coronary artery disease patients: A systematic review and meta-analysis. Sports Med. 2014; 44: 687-700.

27. Pryimakov O, Iermakov S, Kolenkov O. Monitoring of functional fitness of combat athletes during the precompetitive preparation stage. Journal of Physical Education and Sport, 2016; 16 (2): 551-561.

\section{References}

1. Aulyk YV. Opredelenye fyzycheckoi rabotocpocobnocty v klynyke y cporte. M., 1990. 147 c.

2. Babushkyn H.D. Psykholoho-pedahohycheskoe obespechenye podhotovky sportsmenov k sorevnovanyiam. Omsk, 2007. $90 \mathrm{~s}$.

3. Barkanova OV. Metodyky diahnostyky emotsiinoi sfery: psykholohichnyi praktykum. Krasnoiarsk: Literaprynt, 2009; 2: $237 \mathrm{~s}$.

4. Boiko HM. Psykholohichna struktura sportyvnoi diialnosti plavtsiv u paralimpiiskomu sporti. Pedahohika, psykholohiia ta medyko-biolohichni problemy fizychnoho vykhovannia i sportu: 2007; 9: 19-24.

5. Voronova V, Korneiko U. Pokazately psykholohycheskoi hotovnosty vыsokokvalyfytsyrovannыkh sportsmenov. Olympyiskyi sport y sport dlia vsekh: tezysы V Mezhdunarodnoho nauchnoho konhressa (5-7 yiunia 2001). Mynsk: BelorusskaiaHAFK, 2001: 395.

6. Viatkyn BA. Upravlenye psykhycheskym stressom v sportyvnыkh sorevnovanyiakh. M., 1981. $112 \mathrm{~s}$.

7. Ylyn EP. Psykholohyia sporta. Sankt-Peterburh: Pyter 2019. $352 \mathrm{s.}$

8. Ylyn EP, Semenov MS. Psykhofyzyolohycheskye osnovы fyzycheskoho vospytanyia y sporta. Lenynhradskyi hosudarstvennыi pedahohycheskyi ynstytut im. A. Y. Hertsena, Lenynhrad, 1972. 186 s.

9. Karelyn AA. Bolshaia эntsyklopedyia psykholohycheskykh testov. M.: Эksmo, 2007. $416 \mathrm{~s}$.

10. Kyrpenko VM, Zolochevskyi VV, Poltavets AI. Podolannia pereshkod. Smuha pereshkod CISM. Kharkiv: KhNUPS im.I.Kozheduba, 2020. 104 s.

11. Kyrpenko VM, Piddubnyi OH. Poltavets AI. Aeronavtychne bahatoborstvo. Kharkiv: KhNUPS im. I.Kozheduba, 2016. $168 \mathrm{~s}$.

12. Krylov AA. Nekotorbe problemy psykholohyy sporta v sovremennom myre. Sportyvnaia psykholohyia v trudakh otechestvennykh spetsyalystov / Sost. y obshchaia red. Y.P. Volkova. SPb.: Pyter, 2002: 37-42.

13. Landa BKh. Metodyka kompleksnoi otsenky fyzycheskoho razvytyia y fyzycheskoi podhotovlennosty. M.: Sovetskyi sport, 2011. $348 \mathrm{~s}$

14. Mytskan T., Mytskan B. Psykhodiahnostyka v sporti. Ivano-Frankivsk: Vydavets Kushnir H.M., 2020. 228 s.

15. Reikovskyi Ya. Eksperymentalnaia psykholohyia emotsyi. M.: Prohress, 1989. 297 s.

16. Stambulova NB. Psykholohycheskaia struktura sportyvnoi deiatelnosty. Sportyvnaia psykholohyia v trudakh otechestvennykh psykholohov/ Sost. Y.P. Volkov. SPb.: Pyter, 2002: 32-37.

17. Tukaev SV, Dolhova EN, Ruzhenkova A.O., Lusenko EN, Fedorchuk SV, Havrylets YuD., Ryzun VV., Shynkaruk OA. Typolohycheskye y lychnostnыe determynanty stressoustoichyvosty u sportsmenov ekstremalnykh vydov sporta. Sportyvna medytsyna, fizychna terapiia ta erhoterapiia. 2017; 2: 8-15.

18. Khanyn YuL. Psykholohyia obshchenyia v sporte. M.: Fyzkultura y sport, 1980. 208 s.

19. Shcheholev VA, Syvak AN, Kochyn AA, Ehorov VIu. Podhotovka spetsyalystov voenno-sportyvnoho profylia v vooruzhennykh sylakh vedushchykh stran NATO. Teoryia y praktyka fyzycheskoi kultury. 2016; 2: 61-66.

20. Shcherbakov MA, Liannoi MO. Osnovy sportyvnoho oriientuvannia : navchalno-metodychni rekomendatsii. Vyd-vo SumDPU imeni A. S. Makarenka, Sumy, 2015. 32 c.

21. Brymer E., \& Schweitzer R. Extreme sports are good for your health: a phenomenological understanding of fear and anxiety in extreme sport. Journal of health psychology. 2013; 18(4): 477-487. Retrieved from PMID: 22689592, doi: 10.1177/1359105312446770.

22. Galli N., Gonzalez SP. Psychological resilience in sport: A review of the literature and implications for research and practice. International Journal of Sport and Exercise Psychology. 2015; 13(3): 243-257. Retrieved from doi: http://dx.doi.org/10.1080/1612197X.2014.946947.

23. Knapik J., Sharp M., Darakjy S. Temporal changes in the physical fitness of US army recruits, Sports Med. 2006; 36: 613-634.

24. Leyk D, Erley O, Ridder D., Leurs A. Age related changes in marathon and half-marathon performances. Int J Sports Med, 2007; 28: 513-517. 
25. Osipov A., Kudryavtsev M., Gatilov K. The use of functional training - crossfit methods to improve the level of special training of athletes who specialize in combat sambo. Journal of Physical Education and Sport. 2017;17 (3): 2013-2018.

26. Pattyn N., Coeckelberghs E., Buys R. Aerobic interval training vs. moderate continuous training in coronary artery disease patients: A systematic review and meta-analysis. Sports Med. 2014; 44: 687-700.

27. Pryimakov O., Iermakov, S. Kolenkov, O. Monitoring of functional fitness of combat athletes during the precompetitive preparation stage. Journal of Physical Education and Sport, 2016; 16 (2): 551-561.

Цитування на цю статтю:

Полтавець АI, Мулик ВB, Кийко АС. Оцінка емоційно-вольової сфери та реактивної тривожності курсантів в контексті розробки моделі тренувального комплексу для спортсменів 3 військово-авіаційного П’ятиборства. Вісник Прикарпатського університету. Серія: Фізична культура. 2020 Листоп 24; 36: $108-116$

\begin{tabular}{|c|c|}
\hline Відомості про автора: & Information about the author: \\
\hline $\begin{array}{l}\text { Полтавець Андрій Іванович - Харківський націо- } \\
\text { нальний університет Повітряних Сил імені Івана } \\
\text { Кожедуба (Харків, Україна) }\end{array}$ & $\begin{array}{l}\text { Poltavets Andrii Ivanlovych - Ivan Kozhedub Kharkiv } \\
\text { National Air Force University (Kharkiv, Ukraine) }\end{array}$ \\
\hline \multicolumn{2}{|l|}{$\begin{array}{l}\text { e-mail: apoltavec82@ gmail.com } \\
\text { https://orcid.org/0000-0003-0695-4465 }\end{array}$} \\
\hline $\begin{array}{l}\text { Мулик Вячеслав Володимирович - доктор наук з } \\
\text { фізичного виховання і спорту, професор, Харків- } \\
\text { ська державна академія фізичної культури (Харків, } \\
\text { Україна) }\end{array}$ & $\begin{array}{l}\text { Mulyk Viacheslav - Doctor of Science (Physical } \\
\text { Education and Srort), Professor, Kharkiv State } \\
\text { Academy of Physical Culture (Kharkiv, Ukraine) }\end{array}$ \\
\hline \multicolumn{2}{|l|}{$\begin{array}{l}\text { e-mail: mulyk.viacheslav@ gmail.com } \\
\text { https://orsid.org/0000-0002-4441-1253 }\end{array}$} \\
\hline $\begin{array}{l}\text { Кийко Андрій Серхійович - кандидат з фізичного } \\
\text { виховання і спорту, Харківська державна академія } \\
\text { фізичної культури (Харків, Україна) }\end{array}$ & $\begin{array}{l}\text { Kyyko Andrii - Candidate PhD (Physical Education } \\
\text { and Srort), Kharkiv State Academy of Physical Culture } \\
\text { (Kharkiv, Ukraine) }\end{array}$ \\
\hline $\begin{array}{l}\text { e-mail: kiyko8000@ gmail.com } \\
\text { http://orcid.org/0000-0002-6248-3576 }\end{array}$ & \\
\hline
\end{tabular}

